\title{
Effect of Insecticides, Fungicides and Herbicides on Biofertilizer Bacteria and their Consortium
}

\author{
F.S. Manva, H.K. Patel and R.V. Vyas* \\ Department of Agricultural Microbiology, B.A. College of Agriculture, Anand Agricultural \\ University, Anand - 388 110, India \\ *Corresponding author
}

\begin{abstract}
Keywords
Biofertilizer, Insecticide,

Fungicide,

Herbicide,

Compatibility,

Liquid assay

Article Info

Accepted:

07 May 2019

Available Online:

10 June 2019

Combined soil application of Bio NPK and pesticides either simultaneous and sequential can enhanced plant growth parameters effectively and most of the pesticides tested viz. Profenofos 50\% EC, Spinosad 45\% SC, Dichlorvos 76\% EC, Imidacloprid 30.5\% EC, Fipronil 5\% SC, Chlorpyrifos 20\% EC, Pyraclotrobin 20\% WG, Ridomil 68\% WP, Quizalofop 5\% EC and Finoxaprop 9\% EC found safe to beneficial bacteria at the field recommended dose exhibiting no reduction of bacterial population compared with untreated control. However, broad spectrum and combination of fungicide (Mencozeb $63 \%$ + Carbendazim 12\% WP) as well as multiple application of pesticide had inhibitory effect on tested individual bacterial members as well as Bio-NPK consortium. Thus, the studies indicated that all pesticides especially insecticides and herbicides are less detrimental to beneficial bacteria used as biofertilizers in common crop management practices.
\end{abstract}

\section{Introduction}

Micro-organism utilized to enhance availability of the major macronutrients, viz. nitrogen, phosphorus \& potash and other micronutrients to the crops called Biofertilizer.

Biofertilizers are preparation containing active or latent cells of bacteria, fungi and cynobacteria (blue green algae), which enhance grain and straw yields along with plant and soil health. Field experiments were conducted to compare the efficiency of carrier based BGA bio-fertilizer (Khush et al., 1992).

The effect of plant associated microorganism on plant growth and health; they enhance stress tolerance, provide disease resistance, aid nutrient availability and uptake and promote biodiversity (Satyendra et al., 2010). They provide the plant with nutrient, resistance against disease and ability to combat worst climatic conditions (Alkhani et al., 2006). Inoculation with a mixture of Azotobacter and Azospirillum with full doses 
of rock phosphate and inorganic $\mathrm{N}$-fertilizer, in combination with inoculation with vascular arbuscular mycorrhiza (VAM), improved growth of both datura (Datura stramonium) and ammi (Ammi visnaga: Fam. Umbelliferae) plants (Sharaf, 1995). The interaction among the rhizosphere, the root of higher plants and the soil borne microorganism has a significant role in plant growth \& development. The organic compound, released by roots and bacteria play an important role in the uptake of mineral nutrient.

A pesticide is a substance or mixture of substances used for the management of the damage caused by pest.

The pests may be insects, bacteria, fungi, weeds, nematodes, or birds. When pesticides enter in to an organism via water or any other process it participate in the regular metabolism, by which a pesticides or chemical, changed into one or more different chemical (metabolite) within a living organism as a result metabolic product or metabolite, many become either more toxic than the original one.

Biofertilizers are progressively available in India market as one of the substitutes to reduce applications of costly chemical fertilizers in cultivated crops. Liquid biofertilizers enhancing the availability of macro nutrients viz. nitrogen (by fixing atmospheric $\mathrm{N}_{2}$ ), phosphorus and potash (by solubilisation / mobilization from soil) and bacterial consortium (PGPR) formulations are more promising and updated technology (Vyas et al., 2017) having several advantages over the conventional carrier based formulations.

In many studies, it is demonstrated that microorganisms are capable to grow in the presence of noxious pesticides (Chandra et al., 2016). A comprehensive study has been undertaken to investigate the effect of pesticides on five native agriculturally beneficial of liquid biofertilizers and Bio NPK, 'Anubhav' branded products of Anand Agricultural University very popular in farmers of western India for augmenting N, P and $\mathrm{K}$ in agricultural crops.

\section{Materials and Methods}

\section{Pesticide used in the study}

Seven insecticides, five fungicides and three herbicides commonly used in agricultural crop (as mentioned in table 1) are selected for compatibility with individual five bacteria of Bio-NPK and Bio-NPK consortium through agar plate assay and liquid tube assay in laboratory in this study.

\section{Pesticide doses}

All the pesticides were tested at three different doses viz. field recommended dose $(\mathrm{X})$, half the field recommended dose $(1 / 2 \mathrm{X})$ and double the field recommended dose (2X). The Required test doses for the study were prepared in sterile distilled water and appropriate amount of pesticides pipetted in dilution tube under aseptic conditions.

The pesticide in granular/wettable powder form were added at $10 \mathrm{~g}$ of pesticide transferred to the $10 \mathrm{ml}$ of sterile water and thoroughly mixed in sterile screw cap tubes and diluted to achieve desired doses just prior to experimentation.

Quanitiy of tested recommended dose (X)

$=\frac{\text { Desired volume of water } \times \text { Recommended dose of pesticide }}{\text { Quantity of water }}$ 


\section{List if beneficial bacteria (Bio NPK) used in the study}

\begin{tabular}{|l|l|l|}
\hline Sr. No. & Organism & NCBI Accession No \\
\hline 1. & Azotobacter chroococcum & KF494187 \\
\hline 2. & Azospirillum lipoferum & KR706179 \\
\hline 3. & Bacillus tequilensis & JX403935 \\
\hline 4. & Bacillus coagulans & KF933349 \\
\hline 5. & Bacillus licheniformis & - \\
\hline
\end{tabular}

\section{Agar well diffusion method}

The agar plate surface was inoculated by spreading a volume of the microbial inoculum over the entire agar surface. A well with a diameter of $10 \mathrm{~mm}$ was punched aseptically with a sterile cork borer and a volume (20$100 \mu \mathrm{L}$ ) of the pesticide agent or extract solution at desired concentration was introduced into the well. Then, agar plates were incubated in incubator (time depending upon the test bacteria). The pesticides agent diffuses in the agar medium and inhibited growth of the microbial cultures and consortium formulation were tested. Zones or inhibition observed in the plates were considered as sensitive to the particular pesticide while the no inhibition shows the tolerance of bacteria towards particular tested pesticide. All the procedure repeated three times (Nene and Thapliyal, 1993).

\section{Liquid assay}

All the isolates were tested for pesticide tolerance in Nutrient broth with having (100 $\mu 1$ from the prepared doses) field recommended dose (X), half the field recommended dose $(1 / 2 X)$ and double the field recommended dose $(2 \mathrm{X})$ of pesticide keeping uninoculated control. $100 \quad \mu l$ bacterial suspension of A. chroococcum (ABA-1), A. lipoferum (ASA-1), $B$. tequilensis, $B$. coagulans (PBA-16) and B. licheniformis individual and consortium product $\left(5 \times 10^{8}\right)$ $\mathrm{CFU} / \mathrm{ml}$ was inoculated in nutrient broth tubes. Tubes were incubated at $28 \pm 2^{0} \mathrm{C}$ for 3 to 5 days with control. Daily observations for bacterial growth (O.D.) were taken with the help of spectrophotometer at the time interval of 3,4 and 5 days. The bacteria showing growth equal to the growth as in control was considered as compatible while the isolates having little or no growth was considered as sensitive to respective pesticide dose. All the procedure repeated three times (Abaidoo et al., 2002).

\section{Microbial count}

Following serial dilution up to $10^{-7}, 0.1 \mathrm{ml}$ of the respective dilutions were spreaded on respective solid media i.e. Jenson's agar (for Azotobacter), N free BTB agar (for Azospirillum) and sperber (for PSB) and Aleksandrov's media (for KMB) in laboratory studies (Tamizhazhagan et al., 2016).

\section{Results and Discussion}

Results on compatibility of insecticides, fungicides and herbicides on individual bacterial members and Bio-NPK consortium in plate assay (Table 1 to 4 and Plate 1) revealed that growth of all the tested bacteria was not inhibited by the treatment of Spinosad 45\% SC, Fipronil 5\% SC and Imidacloprid 30.5\% EC and Dichlorvos 76\% $\mathrm{EC}$ at all three tested doses. Similar study was also conducted by Gnanchitra et al., (2018) to access effect of Imidacloprid on the growth and multiplication rate of Rhizobium for a strategic eco-friendly seed treatment in pulse and they found that recommended dose of the 
applied insecticide was not effecting survival and nodulation ability of the Rhizobium biofertilizer. Moreover, AAU Bio-NPK consortium found compatible with field recommended dose (X) and half recommended dose $(1 / 2 \mathrm{X})$ of all the tested pesticides. While growth of $A$. chroococcum was found to inhibited by double dose of Finoxaprop 9\% EC, Mencozeb 63\%+ Carbendazim 12\% WP and Quizalofop 5\% EC, similarly for A. lipoferum growth inhibition was observed by double dose of Profenofos 50\% EC and Mencozeb 63\% + Carbendazim 12\% WP for B. licheniformis growth inhibition was observed by double dose of Carbosulfan 25\% EC, Chlorpyrifos $20 \%$ EC, Copper oxychloride 50\% W/W, Mencozeb 63\% + Carbendazim 12\% WP, Propiconazole 25\% EC, Ridomil 68\% WP, Pyraclotrobin 20\% WG, Pendimethalin 38.7\% EC and Quizalofop 5\% EC, for B. tequilensis growth inhibition was observed by double dose of Carbosulfan 25\% EC, Chlorpyrifos $20 \%$ EC , Mencozeb 63\% + Carbendazim $12 \%$ WP, Pyraclotrobin 20\% WG, Quizalofop $5 \%$ EC and Finoxaprop 9\% EC, similarly growth inhibition was observed for Bio-NPK consortium by Copper oxychloride $50 \%$ W/W, Mencozeb 63\% + Carbendazim 12\% WP , Ridomil 68\% WP, Quizalofop 5\% EC and Finoxaprop 9\% EC. Growth inhibition of $A$. chroococcum, A. lipoferum and $B$. coagulans was observed for recommended dose (X) of Mencozeb $63 \%+$ Carbendazim $12 \%$ WP only, similarly for B. licheniformis growth inhibition was observed by Mencozeb $63 \%+$ Carbendazim 12\% WP (Plate 2) and Propiconazole $25 \%$ EC, B. tequilensis growth inhibition was observed by Carbosulfan 25\% EC and Mencozeb 63\% + Carbendazim 12\% WP. Half dose $(1 / 2 \mathrm{X})$ of fungicide Mencozeb $63 \%$ + Carbendazim 12\% WP found to inhibit growth of all the tested individually bacteria. Interestingly, Sethi et al., (2013) studied effects of synthetic pyrethroids on phosphate solubilizing activity of microorganisms.
During their study, they found that, amongst the four synthetic pyrethroid insecticides studied, all of them showed remarkable effect on the populations of P-solubilizing microorganisms. The effect of Deltamethrin on Bacillus, Rhizobium and Pseudomonas was more pronounced as compared to AlphaCyhalothrin, Fenvelerate and Cypermethrin. The application of Cypermethrin inhibited the activity of Pseudomonas and Serratia, significantly as compared to Fenvalerate, Alpha-Cyhalothrin and Deltamethrin. The inhibitory effect of Fenvelerate was more pronounced in case of Pseudomonas, Azotobacter and Rhizobium as compared to other three insecticides. Lastly alphaCyhalothrin did not show any remarkable inhibitory effect on Phospahte solubilizing activity as compared to remaining three insecticides.

Results of the liquid assay revealed that different doses of profenofos, spinosad, dichlorvos, imidacloprid and fipronil were found compatible with all the individual bacterial members and Bio-NPK consortium at all three test doses. While, double dose (2X) of Carbosulfan 25\% EC, Copper oxychloride $50 \% \mathrm{~W} / \mathrm{W}$, Pendimethalin $38.7 \%$ EC, Propiconazole 25\% EC, Ridomil 68\% WP were not found compatible with $B$. licheniformis. Similarly, double dose of Chlorpyrifos 20\% EC and Pyraclotrobin 20\% WG were not found compatible for $B$. tequilensis and B. licheniformis. Moreover, Quizalofop 5\% EC was not found compatible for A. chroococcum, B. tequilensis and $B$. licheniformis at double dose (2X). Finoxaprop 9\% EC was not found compatible for $A$. chroococcum, $B$. licheniformis and $B$. coagulans at double dose. Same way, Mencozeb 63\% + Carbendazim 12\% WP was not found compatible with A. chroococcum, A. lipoferum, B. tequilensis, B. coagulans and $B$. licheniformis and Bio-NPK consortium at double and recommended doses. While, $A$. 
chroococcum, A. lipoferum, B. tequilensis, B. coagulans and $B$. licheniformis and Bio-NPK consortium were found compatible with half dose of Mencozeb 63\% + Carbendazim 12\% WP. As shown in Figure 1 the liquid assay of Pendimethalin $38.7 \%$ EC at three different field recommended doses i.e. $1 / 2 \mathrm{X}, \mathrm{X}$ and $2 \mathrm{X}$, it was found that growth was continuously increased up to 5 days and on $5^{\text {th }}$ day growth was found to be maximum. Growth of $B$. licheniformis is decreased at double doses at 3,4 and 5 days significantly. At $5^{\text {th }}$ day population density of $B$. licheniformis was (1.17) as compare to bacterial inoculated control (1.97). The growth of organisms continuously increased day to day. Pendimethalin $38.7 \%$ EC proved compatible for all the organisms. Moreover, Quizalofop $5 \%$ EC, continuous increase of bacterial growth up to 5 days was reported and on $5^{\text {th }}$ day population density of the broth was found to be maximum. At $5^{\text {th }}$ day density of $A$. chroococcum, $B$. tequilensis and $B$. licheniformis was (1.50), (1.52) and (1.22) as compare to bacterial inoculated control (2.26), (2.26) and (1.97) respectively and found sensitive to the double dose of herbicide. At 3, 4 and 5 days the growth of organism found affected by the double dose of herbicide. Quizalofop 5\% EC is not compatible with $A$. chroococcum, $B$. tequilensis and $B$. licheniformis at double dose only. Hence, other organism A. lipoferum, B. coagulans and Bio-NPK consortium found compatible for any dose for pest management practices. Similarly for Finoxaprop 9\% EC, it was noticed that continuous increase in bacterial growth up to 5 days and on $5^{\text {th }}$ day growth was found to be maximum. At $5^{\text {th }}$ day population density of $A$. chroococcum, $B$. coagulans and $B$. licheniformis was (1.60), (1.56) and (1.12) as compare to bacterial inoculated control (2.26), (2.50) and (1.97) respectively and found sensitive to the double dose of herbicide. Growth of A. chroococcum, $B$. coagulans and $B$. licheniformis found sensitive at double dose at time interval. Thus, Finoxaprop 9\% EC is not compatible with $A$. chroococcum, $B$. coagulans and $B$. licheniformis at double dose.

Gaherval et al., (2015) studied the impact of chemical (2, 4-D, dimethoate and carbendazin) and herbal product by well diffusion, disk diffusion and MIC methods, on nitrogen fixers against Rhizobium, Azotobacter and Azospirillum and found that growth inhibition against all three bacteria was different and veering. Carbendazim showed the zone of inhibition against Azospirillum and Rhizobium bacteria but did not show inhibition against Azotobacter. Laboratory evaluation indicated that amongst pesticides, insecticides and herbicides are less detrimental to beneficial bacteria useful as biofertilizers in cotton crop practices at recommended dose.

Table.1 Pesticides used in the study

\begin{tabular}{|c|l|l|l|}
\hline Sr. No. & \multicolumn{1}{|c|}{ Insecticides } & \multicolumn{1}{|c|}{ Fungicides } & \multicolumn{1}{|c|}{ Herbicides } \\
\hline $\mathbf{1}$ & Profenofos 50\% EC & Copper oxychloride 50\% W/W & Pendimethalin 38.7\% EC \\
\hline $\mathbf{2}$ & Spinosad 45\% SC & Mencozeb 63\% + Carbendazim 12\% WP & Quizalofop 5\% EC \\
\hline $\mathbf{3}$ & Fipronil 5\% SC & Propiconazole 25\% EC & Finoxaprop 9\% EC \\
\hline $\mathbf{4}$ & Imidacloprid 30.5\% EC & Ridomil 68\% WP & \\
\hline $\mathbf{5}$ & Dichlorvos 76\% EC & Pyraclotrobin 20\% WG & \\
\hline $\mathbf{6}$ & Carbosulfan 25\% EC & & \\
\hline $\mathbf{7}$ & Chlorpyrifos 20\% EC & & \\
\hline
\end{tabular}


Table. 2 Effect of different pesticides on individual bacterial member as well as Bio-NPK consortium

\begin{tabular}{|c|c|c|c|c|c|c|c|c|c|c|c|c|c|c|c|}
\hline \multirow[t]{4}{*}{ Treatment } & \multicolumn{15}{|c|}{ Zone of inhibition (mm) } \\
\hline & \multirow{2}{*}{\multicolumn{3}{|c|}{$\begin{array}{c}\text { Profenofos } \\
\text { 50\% EC } \\
\text { Dose }\end{array}$}} & \multirow{2}{*}{\multicolumn{3}{|c|}{$\begin{array}{c}\text { Spinosad } \\
\text { 45\% SC } \\
\text { Dose }\end{array}$}} & \multirow{2}{*}{\multicolumn{3}{|c|}{$\begin{array}{c}\text { Fipronil 5\% } \\
\text { SC } \\
\text { Dose }\end{array}$}} & \multirow{2}{*}{\multicolumn{3}{|c|}{$\begin{array}{c}\text { Imidacloprid } \\
\text { 30.5\% EC } \\
\text { Dose }\end{array}$}} & \multirow{2}{*}{\multicolumn{3}{|c|}{\begin{tabular}{|c|} 
Dichlorvos \\
$76 \%$ EC \\
Dose
\end{tabular}}} \\
\hline & & & & & & & & & & & & & & & \\
\hline & $1 / 2 X$ & $\mathbf{X}$ & $2 X$ & $1 / 2 X$ & $\mathbf{X}$ & $2 X$ & $1 / 2 X$ & $\mathbf{X}$ & $2 X$ & $1 / 2 X$ & $\mathbf{X}$ & $2 X$ & $1 / 2 X$ & $\mathbf{X}$ & $2 X$ \\
\hline A. chroococcum & $\mathrm{R}$ & $\mathrm{R}$ & $\mathrm{R}$ & $\mathrm{R}$ & $\mathrm{R}$ & $\mathrm{R}$ & $\mathrm{R}$ & $\mathrm{R}$ & $\mathrm{R}$ & $\mathrm{R}$ & $\mathrm{R}$ & $\mathrm{R}$ & $\mathrm{R}$ & $\mathrm{R}$ & $\mathrm{R}$ \\
\hline A. lipoferum & $\mathrm{R}$ & $\mathrm{R}$ & 5 & $\mathrm{R}$ & $\mathrm{R}$ & $\mathrm{R}$ & $\mathrm{R}$ & $\mathrm{R}$ & $\mathrm{R}$ & $\mathrm{R}$ & $\mathrm{R}$ & $\mathrm{R}$ & $\mathrm{R}$ & $\mathrm{R}$ & $\mathrm{R}$ \\
\hline B. licheniformis & $\mathrm{R}$ & $\mathrm{R}$ & $\mathrm{R}$ & $\mathrm{R}$ & $\mathrm{R}$ & $\mathrm{R}$ & $\mathrm{R}$ & $\mathrm{R}$ & $\mathrm{R}$ & $\mathrm{R}$ & $\mathrm{R}$ & $\mathrm{R}$ & $\mathrm{R}$ & $\mathrm{R}$ & $\mathrm{R}$ \\
\hline B. tequilensis & $\mathrm{R}$ & $\mathrm{R}$ & $\mathrm{R}$ & $\mathrm{R}$ & $\mathrm{R}$ & $\mathrm{R}$ & $\mathrm{R}$ & $\mathrm{R}$ & $\mathrm{R}$ & $\mathrm{R}$ & $\mathrm{R}$ & $\mathrm{R}$ & $\mathrm{R}$ & $\mathrm{R}$ & $\mathrm{R}$ \\
\hline B. coagulans & $\mathrm{R}$ & $\mathrm{R}$ & $\mathrm{R}$ & $\mathrm{R}$ & $\mathrm{R}$ & $\mathrm{R}$ & $\mathrm{R}$ & $\mathrm{R}$ & $\mathrm{R}$ & $\mathrm{R}$ & $\mathrm{R}$ & $\mathrm{R}$ & $\mathrm{R}$ & $\mathrm{R}$ & $\mathrm{R}$ \\
\hline Bio-NPK & $\mathrm{R}$ & $\mathrm{R}$ & $\mathrm{R}$ & $\mathrm{R}$ & $\mathrm{R}$ & $\mathrm{R}$ & $\mathrm{R}$ & $\mathrm{R}$ & $\mathrm{R}$ & $\mathrm{R}$ & $\mathrm{R}$ & $\mathrm{R}$ & $\mathrm{R}$ & $\mathrm{R}$ & $\mathrm{R}$ \\
\hline Control & $\mathrm{R}$ & $\mathrm{R}$ & $\mathrm{R}$ & $\mathrm{R}$ & $\mathrm{R}$ & $\mathrm{R}$ & $\mathrm{R}$ & $\mathrm{R}$ & $\mathrm{R}$ & $\mathrm{R}$ & $\mathrm{R}$ & $\mathrm{R}$ & $\mathrm{R}$ & $\mathrm{R}$ & $\mathrm{R}$ \\
\hline
\end{tabular}

Table.3 Effect of different pesticides on individual bacterial member as well as Bio-NPK consortium

\begin{tabular}{|c|c|c|c|c|c|c|c|c|c|c|c|c|c|c|c|}
\hline \multirow[t]{4}{*}{ Treatment } & \multicolumn{15}{|c|}{ Zone of inhibition (mm) } \\
\hline & \multirow{2}{*}{\multicolumn{3}{|c|}{$\begin{array}{c}\text { Carbosulfan } \\
25 \% \text { EC }\end{array}$}} & \multicolumn{3}{|c|}{$\begin{array}{c}\text { Chlorpyrifos } \\
20 \% \text { EC }\end{array}$} & \multirow{2}{*}{\multicolumn{3}{|c|}{$\begin{array}{c}\text { Copper } \\
\text { oxychloride } \\
50 \% \text { W/W } \\
\text { Dose }\end{array}$}} & \multirow{2}{*}{\multicolumn{3}{|c|}{$\begin{array}{c}\text { Mancozeb } 63 \%+ \\
\text { Carbendazim } 12 \% \\
\text { WP } \\
\text { Dose }\end{array}$}} & \multicolumn{3}{|c|}{$\begin{array}{c}\text { Propiconazole } \\
25 \% \text { EC }\end{array}$} \\
\hline & & & & & ose & & & & & & & & & Do & \\
\hline & $1 / 2 X$ & $\mathbf{X}$ & $2 X$ & $1 / 2 X$ & $\mathbf{X}$ & $2 X$ & $1 / 2 X$ & $\mathbf{X}$ & $2 X$ & $1 / 2 X$ & $\mathbf{X}$ & $2 X$ & $1 / 2 X$ & $\mathbf{X}$ & $2 X$ \\
\hline A. chroococcum & $\mathrm{R}$ & $\mathrm{R}$ & $\mathrm{R}$ & $\mathrm{R}$ & $\mathrm{R}$ & $\mathrm{R}$ & $\mathrm{R}$ & $\mathrm{R}$ & $\mathrm{R}$ & 4 & 5 & 7 & $\mathrm{R}$ & $\mathrm{R}$ & $\mathrm{R}$ \\
\hline A. lipoferum & $\mathrm{R}$ & $\mathrm{R}$ & $\mathrm{R}$ & $\mathrm{R}$ & $\mathrm{R}$ & $\mathrm{R}$ & $\mathrm{R}$ & $\mathrm{R}$ & $\mathrm{R}$ & 3 & 5 & 7 & $\mathrm{R}$ & $\mathrm{R}$ & $\mathrm{R}$ \\
\hline B. licheniformis & $\mathrm{R}$ & $\mathrm{R}$ & 15 & $\mathrm{R}$ & $\mathrm{R}$ & 9 & $\mathrm{R}$ & $\mathrm{R}$ & 9 & 5 & 8 & 10 & $\mathrm{R}$ & 5 & 9 \\
\hline B. tequilensis & $\mathrm{R}$ & 8 & 10 & $\mathrm{R}$ & $\mathrm{R}$ & 14 & $\mathrm{R}$ & $\mathrm{R}$ & $\mathrm{R}$ & 4 & 6 & 8 & $\mathrm{R}$ & $\mathrm{R}$ & $\mathrm{R}$ \\
\hline B. coagulans & $\mathrm{R}$ & $\mathrm{R}$ & $\mathrm{R}$ & $\mathrm{R}$ & $\mathrm{R}$ & $\mathrm{R}$ & $\mathrm{R}$ & $\mathrm{R}$ & $\mathrm{R}$ & 3 & 5 & 6 & $\mathrm{R}$ & $\mathrm{R}$ & $\mathrm{R}$ \\
\hline Bio-NPK & $\mathrm{R}$ & $\mathrm{R}$ & $\mathrm{R}$ & $\mathrm{R}$ & $\mathrm{R}$ & $\mathrm{R}$ & $\mathrm{R}$ & $\mathrm{R}$ & 5 & $\mathrm{R}$ & $\mathrm{R}$ & 8 & $\mathrm{R}$ & $\mathrm{R}$ & $\mathrm{R}$ \\
\hline Control & $\mathrm{R}$ & $\mathrm{R}$ & $\mathrm{R}$ & $\mathrm{R}$ & $\mathrm{R}$ & $\mathrm{R}$ & $\mathrm{R}$ & $\mathrm{R}$ & $\mathrm{R}$ & $\mathrm{R}$ & $\mathrm{R}$ & 0 & $\mathrm{R}$ & $\mathrm{R}$ & $\mathrm{R}$ \\
\hline
\end{tabular}

Note: $\mathrm{R}$ stands for resistant $(0 \mathrm{~mm})$

Table.4 Effect of different pesticides on individual bacterial member as well as Bio-NPK consortium

\begin{tabular}{|c|c|c|c|c|c|c|c|c|c|c|c|c|c|c|c|}
\hline \multirow[t]{4}{*}{ Treatment } & \multicolumn{15}{|c|}{ Zone of inhibition (mm) } \\
\hline & \multirow{2}{*}{\multicolumn{3}{|c|}{$\begin{array}{c}\text { Ridomil 68\% } \\
\text { WP } \\
\text { Dose }\end{array}$}} & \multirow{2}{*}{\multicolumn{3}{|c|}{$\begin{array}{c}\text { Pyraclostrobin } \\
\text { 20\% WG } \\
\text { Dose }\end{array}$}} & \multirow{2}{*}{\multicolumn{3}{|c|}{$\begin{array}{c}\text { Pendimethalin } \\
\text { 38.7\% EC } \\
\text { Dose }\end{array}$}} & \multirow{2}{*}{\multicolumn{3}{|c|}{$\begin{array}{c}\text { Quizalofop } \\
\text { 5\% EC } \\
\text { Dose }\end{array}$}} & \multirow{2}{*}{\multicolumn{3}{|c|}{$\begin{array}{c}\text { Finoxaprop } \\
\text { 9\% EC } \\
\text { Dose }\end{array}$}} \\
\hline & & & & & & & & & & & & & & & \\
\hline & $1 / 2 X$ & $\mathbf{X}$ & $2 X$ & $1 / 2 X$ & $\mathbf{X}$ & $2 X$ & $1 / 2 X$ & $\mathbf{X}$ & $2 X$ & $1 / 2 X$ & $\mathbf{X}$ & $2 X$ & $1 / 2 X$ & $\mathbf{X}$ & $2 X$ \\
\hline A. chroococcum & $\mathrm{R}$ & $\mathrm{R}$ & $\mathrm{R}$ & $\mathrm{R}$ & $\mathrm{R}$ & $\mathrm{R}$ & $\mathrm{R}$ & $\mathrm{R}$ & $\mathrm{R}$ & $\mathrm{R}$ & $\mathrm{R}$ & 11 & $\mathrm{R}$ & $\mathrm{R}$ & 10 \\
\hline A. lipoferum & $\mathrm{R}$ & $\mathrm{R}$ & $\mathrm{R}$ & $\mathrm{R}$ & $\mathrm{R}$ & $\mathrm{R}$ & $\mathrm{R}$ & $\mathrm{R}$ & $\mathrm{R}$ & $\mathrm{R}$ & $\mathrm{R}$ & 0 & $\mathrm{R}$ & $\mathrm{R}$ & 0 \\
\hline B. licheniformis & $\mathrm{R}$ & $\mathrm{R}$ & 8 & $\mathrm{R}$ & $\mathrm{R}$ & 9 & $\mathrm{R}$ & $\mathrm{R}$ & 14 & $\mathrm{R}$ & $\mathrm{R}$ & 9 & $\mathrm{R}$ & $\mathrm{R}$ & 0 \\
\hline B. tequilensis & $\mathrm{R}$ & $\mathrm{R}$ & $\mathrm{R}$ & $\mathrm{R}$ & $\mathrm{R}$ & $\mathrm{R}$ & $\mathrm{R}$ & $\mathrm{R}$ & $\mathrm{R}$ & $\mathrm{R}$ & $\mathrm{R}$ & 7 & $\mathrm{R}$ & $\mathrm{R}$ & 0 \\
\hline B. coagulans & $\mathrm{R}$ & $\mathrm{R}$ & $\mathrm{R}$ & $\mathrm{R}$ & $\mathrm{R}$ & $\mathrm{R}$ & $\mathrm{R}$ & $\mathrm{R}$ & $\mathrm{R}$ & $\mathrm{R}$ & $\mathrm{R}$ & 5 & $\mathrm{R}$ & $\mathrm{R}$ & 7 \\
\hline Bio-NPK & $\mathrm{R}$ & $\mathrm{R}$ & 6 & $\mathrm{R}$ & $\mathrm{R}$ & $\mathrm{R}$ & $\mathrm{R}$ & $\mathrm{R}$ & $\mathrm{R}$ & $\mathrm{R}$ & $\mathrm{R}$ & 6 & $\mathrm{R}$ & $\mathrm{R}$ & 6 \\
\hline Control & $\mathrm{R}$ & $\mathrm{R}$ & $\mathrm{R}$ & $\mathrm{R}$ & $\mathrm{R}$ & $\mathrm{R}$ & $\mathrm{R}$ & $\mathrm{R}$ & $\mathrm{R}$ & $\mathrm{R}$ & $\mathrm{R}$ & $\mathrm{R}$ & $\mathrm{R}$ & $\mathrm{R}$ & $\mathrm{R}$ \\
\hline
\end{tabular}


Fig.1 Effect of Pendimethalin 38.7\% EC on individual bacteria and Bio-NPK consortium by liquid assay

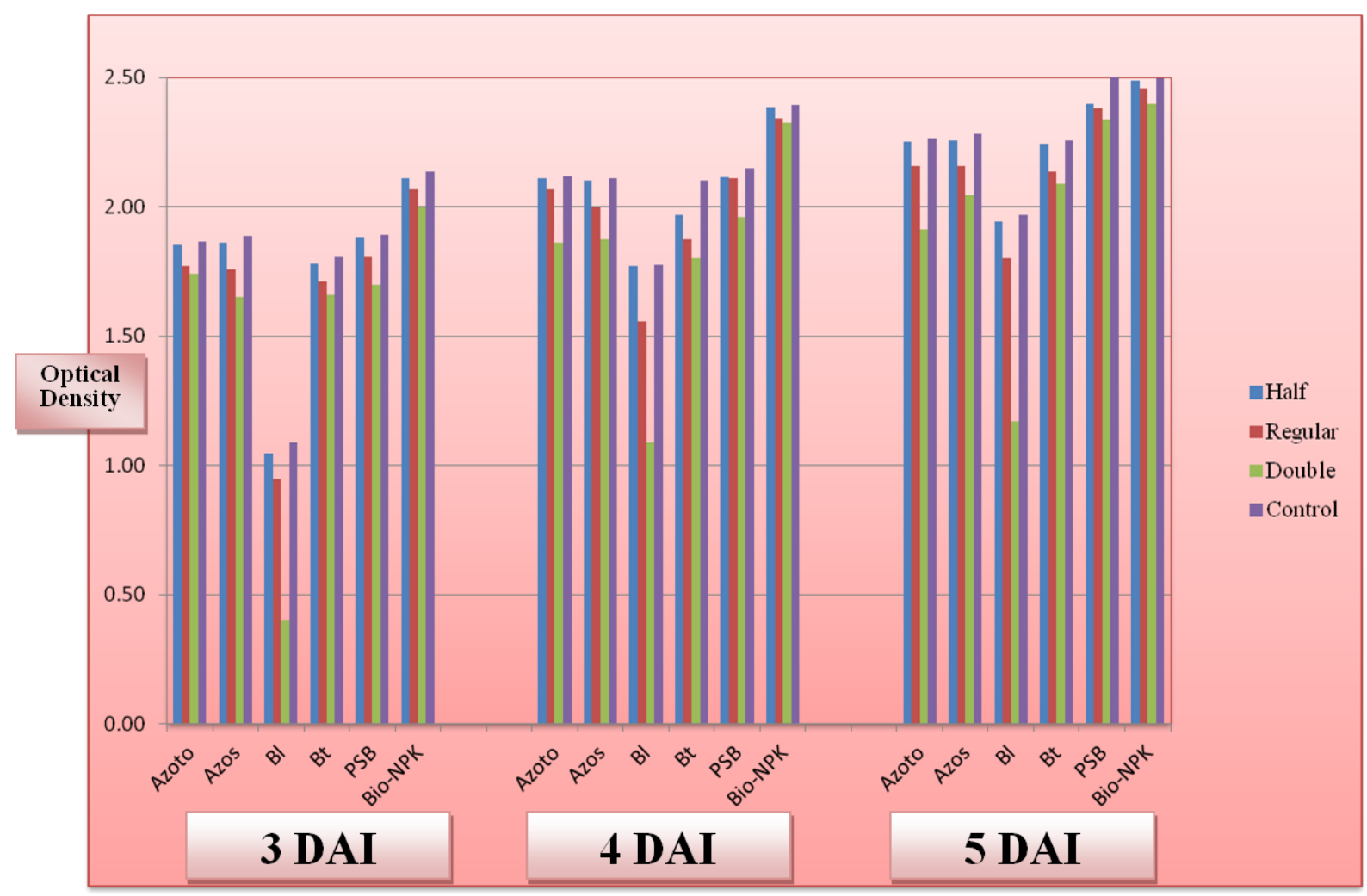

Plate.1 Compatibility of Bio-NPK consortium at field recommended dose with A) Finoxaprop 9\% EC, B) Dichlorvos 76\% EC, C) Carbosulfan 25\% EC, D) Pendimethalin 38.7\% EC, E) Spinosad $45 \%$ SC and F) Propiconazole $25 \%$ EC by plate bio assay

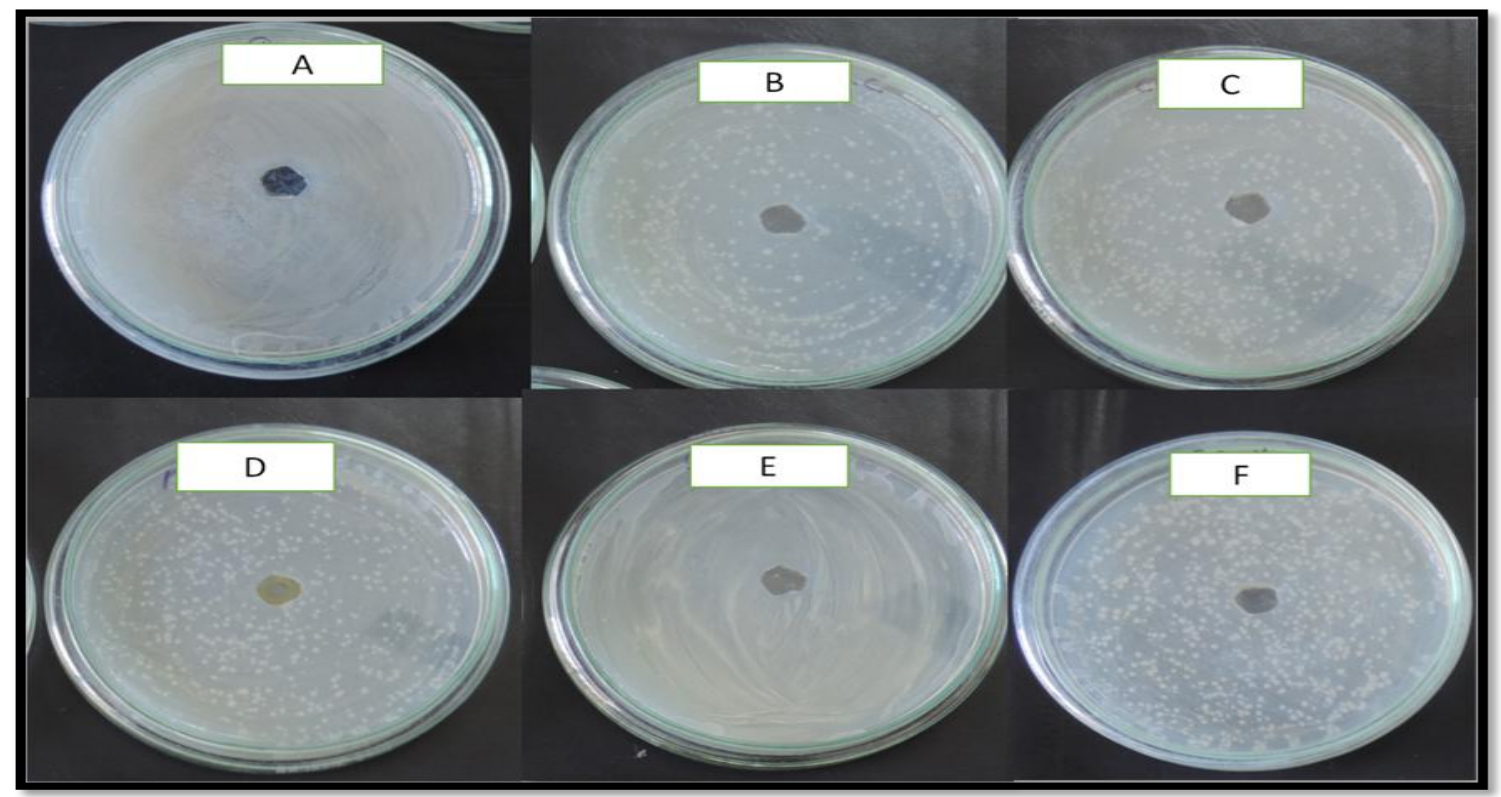


Plate.2 Compatibility of different doses of Mancozeb 63\% + Carbendazim 12\% WP with $B$. licheniformis

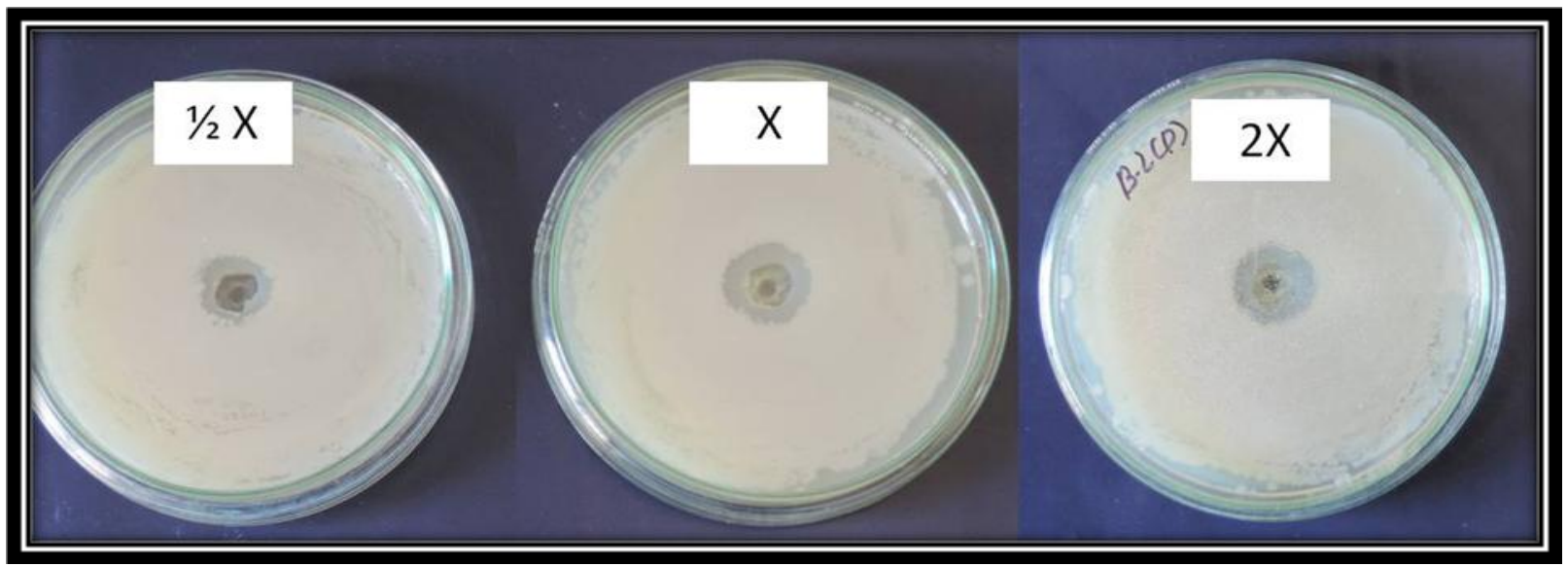

However, indiscriminate use of pesticides on crop like double the field recommended dose application can exert some harmful effect, but broad spectrum and combination of fungicide as well as multiple application of pesticide are detrimental to tested individual bacterial members as well as Bio-NPK consortium. Thus all the pesticides are not harmful to beneficial bacteria used in crop management practices.

In conclusion, different pesticides at their recommended doses found compatible with representative soil beneficial microorganisms. But, higher concentration (dose) in comparison to recommended doses found to act negatively on soil beneficial microorganisms. Interestingly soil applied insecticides and herbicides commonly used in crop management practices are recorded with less detrimental to beneficial bacteria in compare to fungicides, particularly combination of new fungicide molecules.

\section{References}

Abaidoo, R. C., Keyser, H. H., Singletonand, P. W. and Borthaku, D. 2002. Comparison of molecular and antibiotic resistance profile methods for the population analysis of Bradyrhizobium spp. Journal of Applied Microbiology, 92 (1): 109-117.

Alkhani, H. A., Saleh-Rastin, N. and Autoun, H. 2006. Resistance against disease. Plant and soil, 287: 35-41.

Chandra, P. B., Ingle, R. W., and Tetali, S. 2016. Compatibility of Phosphate solubilizing microorganisms with different agrochemicals. Plant Archives, 16 (1): 229-232.

Gaherwal, S., Prakash, M. M., Khasdeo, K. and Anirudh S. 2015. Impact of Selected Chemical and Herbal Pesticide on Beneficial Soil Microorganism. International Journal of Microbiology Research, 6 (3): 236-239.

Gnanachitra, M., Satya, V.K. and Akiladevi, P. 2018. In vitro Estimation on the Effect of Imidacloprid on the Growth and Multiplication Rate of Rhizobium for a Strategic-Ecofriendly Seed Treatment in Pulse. International Journal of Current Microbiology and Applied Science, 7(04): 3705-3710. Doi: https://doi.org/10.20546/ijcmas.2018.70 4.416

Khush, G.S. and Bennet, J. 1992. Nodulation \& nitrogen fixation rice. Potential \& prospect: International Rice Research Institute Press, Mannila, Philippines. P.136. 
Nene, Y. L., and Thapliyal, P. N. 1993. Poison food technique. Fungicides in Plant Disease Control, 2: 413-415.

Satyendra, L., Srivastava, K. and Singh, P. 2010. Effect of blue green algae as biofertilizer on yield. Department of Botany, D.B.S. College Kanpur U.P. 3: 23-29.

Sethi, S., Mathur, N. and Bhatnagar, P. 2013. Effects of synthetic pyrethroids on phosphate solubilizing activity of microorganisms. International Journal of Current Microbiology and Applied Science, 2(12): 240-246.

Sharaf, M. A. 1995. Aromatic Plants Department, National Research Center,
Cairo, Egypt. Int. Agrophysico, 21, 361366.

Tamizhazhagan, V., Pugazhendy K., Sakthidasan, V., Revathi, K. and Baranitharan, M. 2016. Investigation of microbial count in the soil and earthworm gut. Innovare Journal of Agricultural Science, 4 (3): 7-9

Vyas, R. V., Panpatte, D. G., Jhala, Y. K. and Shelat, H. N. 2017. Wonders of Microbes in Agriculture for Productivity and Sustainability in Microorganisms for Green Revolution (pp. 1-23). Springer, Singapore.

\section{How to cite this article:}

Manva, F.S., H.K. Patel and Vyas, R.V. 2019. Effect of Insecticides, Fungicides and Herbicides on Biofertilizer Bacteria and their Consortium. Int.J.Curr.Microbiol.App.Sci. 8(06): 691-699. doi: https://doi.org/10.20546/ijcmas.2019.806.080 